\title{
SUITABILITY OF HAMMOND'S METHOD FOR DETERMINING LANDFORM UNITS IN SLOVENIA
}

\section{PRIMERNOST HAMMONDOVE METODE ZA DOLOCANJE ENOT OBLIKOVANOSTI POVRSJA V SLOVENIJI}

Mauro Hrvatin, Drago Perko

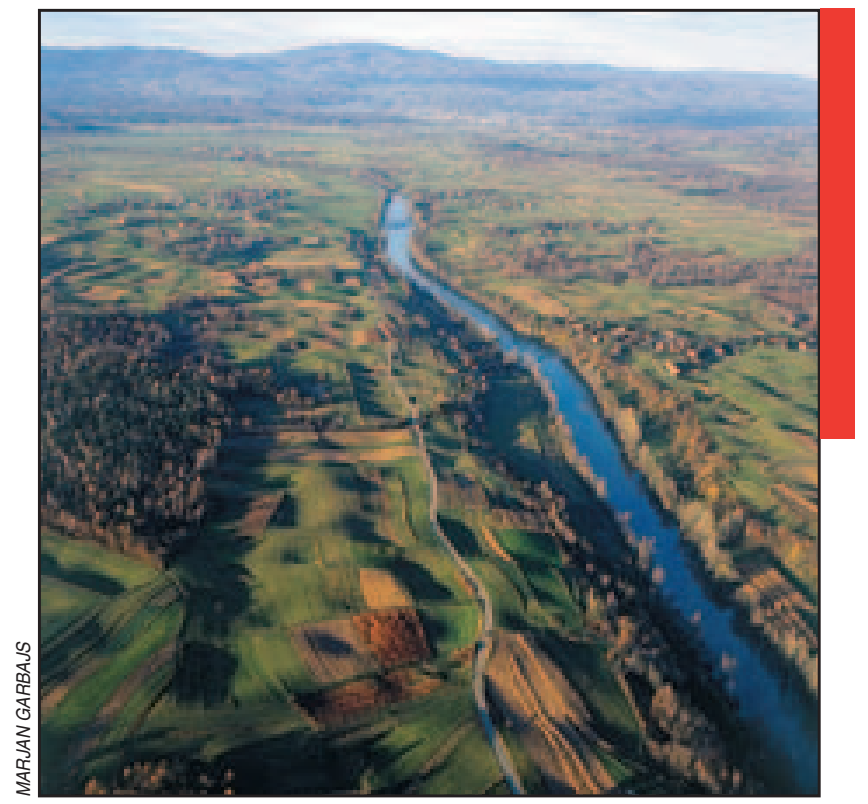

Bela krajina je rahlo valovita pokrajina v jugovzhodni Sloveniji. White Carniola is a slightly undulating region in southeast Slovenia. 


\title{
Suitability of Hammond's method for determining landform units in Slovenia
}

DOI: $10.3986 / A G S 49204$

UDC: 911.2:551.43(497.4)

COBISS: 1.01

\begin{abstract}
Landform is often the most important factor in distinguishing between regions and an important element of geographic classification, typification, and regionalization; this is why morphological classification has had a long tradition in Slovenia and abroad. One of the best-known classifications was developed by the American geographer Edwin H. Hammond, who classified the landforms of the United States in great detail. Later on, his method was applied several times using a geographic information system and digital elevation model. Computer land-surface classification became more objective, whereas the selection of classification elements and their classes remained subjective.

Hammond's method of determining landform units is known throughout the world and this is why it has also been tested in Slovenia. First, the original classification elements were taken into account and only thirteen units of the twenty-one landform units specified by Hammond were selected. Due to weaknesses that were revealed, Hammond's original method was suitably adapted: the form and size of the basic window and the boundaries between classification element classes were changed. Nineteen landform units were thus identified in Slovenia using the adapted method.
\end{abstract}

KEYWORDS: geomorphology, landform unit, Hammond's method, geographic information system, digital elevation model, Slovenia

The article was submitted for publication on October 5, 2009.

ADDRESSES:

\section{Mauro Hrvatin}

Anton Melik Geographical Institute

Scientific Research Centre of the Slovenian Academy of Sciences and Arts

Gosposka ulica 13, SI - 1000 Ljubljana, Slovenia

E-mail: mauro@zrc-sazu.si

Drago Perko, Ph. D.

Anton Melik Geographical Institute

Scientific Research Centre of the Slovenian Academy of Sciences and Arts

Gosposka ulica 13, SI - 1000 Ljubljana, Slovenia

E-mail:drago@zrc-sazu.si

\section{Contents}

1 Introduction 345

2 Description of Hammond's method 346

3 Types of Hammond's landform units 347

$4 \quad$ Hammond's landform units in Slovenia $\quad 348$

Adaptation of Hammond's method
to Slovenia's surface characteristics

6 Conclusion 352

7 References 354 


\section{Introduction}

Because of Slovenia's diverse relief, landform is often the most important factor in distinguishing between regions and is an important element of geographic classification, typification, and regionalization (Perko 2001; Perko 2007); this is why Slovenian geographers have developed several relief-based landform classifications of the territory.

The oldest landform typification was developed by Anton Melik, who distinguished between sixteen landform units on his geomorphological map of Slovenia (Melik 1935):

- High mountains,

- Medium-mountain areas with high-mountain ridges,

- Medium-mountain areas,

- Low mountains,

- High hills,

- Shaly-limestone low mountains of the Pannonian-Rhodope zone above $550 \mathrm{~m}$,

- Shaly-limestone low mountains of the Pannonian-Rhodope zone below $550 \mathrm{~m}$,

- Limestone plateaus above $400 \mathrm{~m}$,

- Limestone plateaus below $400 \mathrm{~m}$,

- Flysch low mountains in the coastal region,

- Flysch low hills in the coastal region,

- Lower Tertiary low mountains in the Pannonian part of the country,

- Upper Tertiary low mountains in the Pannonian part of the country,

- Low hills with low mountains in Dinaric basins and lowlands,

- Large Lower-Pleistocene terraces in the Subpannonian region,

- Plains.

Melik broke down the medium-mountain areas with high-mountain ridges, medium-mountain areas, low mountains, and high hills even further in terms of the individual units' rock structure. It is worth mentioning that this geomorphological map does not entirely match its description. For example, the description states that low hills are the most widely represented in the Subpannonian region, whereas on the map they are drawn only in the Mediterranean region.

After a long pause, Karel Natek prepared a new landform classification, distinguishing between eight landform types (Natek 1993):

- Plains (i.e., flat land with a relief amplitude up to $30 \mathrm{~m}$, mostly in fluvial and fluvioglacial alluviums);

- Low hills (i.e., ridge-and-valley landform with a 30-200 m relief amplitude, mostly in Miocene-Pliocene rocks);

- Low mountains (i.e., ridge-and-valley landform with a relief amplitude above $200 \mathrm{~m}$, reaching the upper timber line);

- High mountains (i.e., areas above the upper timber line, mostly high-mountain karst);

- Low karst (i.e., mostly flat areas or low hills and dells in between at relatively lower elevations than the surrounding terrain);

- High karst (i.e., high plateaus and low mountains with a relief amplitude above $200 \mathrm{~m}$ in the »Dinaric direction « [northwest-southeast] and karst dells in between);

- Low fluviokarst (i.e., karst areas with predominantly fluvio-denudation landforms at relatively lower elevations than the surrounding terrain);

- High fluiokarst (i.e., mostly low mountains with predominantly fluvio-denudation forms).

The first computerized typification was developed by Drago Perko in his doctoral dissertation, in which he divided Slovenian territory into eight landform units (Perko 1992; Perko 2001):

- Unrough plains,

- Rough plains,

- Unrough low hills,

- Rough low hills,

- Unrough high hills,

- Rough high hills,

- Mountains,

- Large valleys. 
Perko identified surface roughness using a relief coefficient (i.e., the geometric mean of the height and slope coefficients, which are based on the spatial changes in relief elevations and inclinations). Perko then used a geographic information system to filter the relief coefficient layer several times, thus obtaining uniform areas of the same morphological class, which he called morphological units (Perko 2001). Later on, he used a similar method to define morphological units on the basis of the height and aspect coefficients, which are based on spatial changes in relief elevations and aspects, and the joint coefficient, which represents the geometric mean of the first two (Perko 2007; Perko 2009).

Another classification was developed by Matej Gabrovec and Mauro Hrvatin for the Geografski atlas Slovenije (Geographical Atlas of Slovenia). They divided Slovenia into six landform units (Gabrovec \&Hrvatin 1998):

- Plains (i.e., low flat areas),

- Low hills (i.e., areas with an up to $300 \mathrm{~m}$ difference in elevation between ridges and valleys),

- Low mountains (i.e., areas with 300-1000 m difference in elevation between ridges and valleys),

- Mountains (i.e., areas whose peaks and ridges reach above the timber line, or over 1,700 m),

- Low plateaus (i.e., high flat areas up to $700 \mathrm{~m}$ in elevation),

- High plateaus (i.e., high flat areas above an elevation of $1,000 \mathrm{~m}$ ).

Morphological landform classifications also have a tradition going back several decades elsewhere around the world. One of the best known was developed by the American geographer Edwin H. Hammond, who first focused on the landform classification of North and South America on small-scale maps (Hammond 1954). Hammond divided the territory of both continents into squares of 7.5 minutes of latitude and 7.5 minutes of longitude. Then he determined the maximum elevation difference, the percentage of area where the ground was flat (less than $8 \%$ slope), and the percentage of flat terrain that occurs in lowland areas for each window. Based on the last element, he distinguished between plains, where the majority of flat terrain lies in lowland areas, and plateaus, where the majority of flatland lies in upland areas.

By combining all three elements, he then divided both continents' landforms into eight units:

- Nearly flat plains,

- Rolling and irregular plains,

- Plains with widely-spaced hills or mountains,

- Partially dissected tablelands,

- Hills,

- Low mountains,

- High mountains,

- Ice caps.

Hammond's detailed landform classification of the United States had an even greater impact (Hammond 1964). His method was later used several times with the support of computers and a digital elevation model. Richard Dikau was the first to successfully apply Hammond's method to a computer algorithm in 1991 in his landform classification of New Mexico; he was followed in 1998 by Lars Brabyn in New Zealand, and in 2005 by Alisa L. Gallant et al. in Alaska.

Lengthy and time-consuming landform classifications using maps were thus replaced by faster and more accurate classifications using a computer-assisted geographic information system. These classifications are more objective, although the selection of classification elements and their classes remain subjective. Junko Iwahashi and Richard J. Pike prepared an overview of twelve landform classifications published in recent years, and all of them were developed using computers (Iwahashi \& Pike 2006).

\section{Description of Hammond's method}

In his detailed landform classification of the United States, Hammond used a square window of $6 \times 6$ miles (approx. $9.65 \times 9.65 \mathrm{~km}$ ) and an area of $93.12 \mathrm{~km}^{2}$ as the basic unit; this may seem large, but in terms of the United States this accounts for only 0.00001 of its territory. The windows followed one another with no overlap. On a 1:250,000 scale topographic map, he identified three elements in each window: slope, local relief, and profile type. He marked every element with a specific sign and defined landform unit through their combinations. 
The first element of Hammond's classification is slope. For each window, he calculated what percentage of its area had a slope less than eight percent (or approx. $4.57^{\circ}$ ). He marked this element with a capital letter:

- A: $>80 \%$ gently sloping terrain,

- B: $50-80 \%$ gently sloping terrain,

- C: $20-50 \%$ gently sloping terrain,

- D: $<20 \%$ gently sloping terrain.

The second element of Hammond's classification is local relief. He calculated the difference between the maximum and minimum elevation for each window. He marked this element with numbers:

- 1: 0-30 m,

- 2: 30-90 m,

- 3: $90-150 \mathrm{~m}$,

- 4: $150-300 \mathrm{~m}$

- 5: 300-900 m,

- 6: 900-1,500 m.

The third element of Hammond's classification is profile type. For each window, he calculated what percentage of gently sloping terrain lay below or above the window's average elevation. He marked this element with a lower-case letter:

- a: $>75 \%$ of gently sloping terrain lying in lowland areas,

- b: $50-75 \%$ of gently sloping terrain lying in lowland areas,

- c: $50-75 \%$ of gently sloping terrain lying in upland areas,

- $\mathrm{d}$ : $>75 \%$ of gently sloping terrain lying in upland areas.

By combining these elements, Hammond identified landform units and put them on a large 1:5,000,000-scale color map. However, he did not present the classification results in the form of squares, but through boundaries between the landform units that he defined subjectively by following the edges of plains, plateaus, low mountains, and similar large relief forms. Because of this, the map is somewhat generalized, but considerably less cluttered.

Because Hammond's method of determining landform units is well known throughout the world, we also decided to test it in Slovenia. In doing this, the original classification elements and their classes were taken into account. A 25-meter digital elevation model was used as the information source instead of a $1: 250,000$ scale map, which is why each basic square window included 148,996 points.

The Scientific Research Center of the Slovenian Academy of Sciences and Arts developed a 25-meter digital elevation model in 2005 for the Surveying and Mapping Authority of the Republic of Slovenia (Podobnikar 2002; Podobnikar 2005; Podobnikar 2006). The model is composed of data on the elevation of points moving from north to south and east to west in increments of 25 meters, representing the vertices of $25 \mathrm{~m} \times 25 \mathrm{~m}$ square windows with a 35 -meter diagonal and the area of $625 \mathrm{~m}^{2}$ (Digitalni ... 2005). The test showed that the model's accuracy for all of Slovenia was $3.2 \mathrm{~m}: 1.1 \mathrm{~m}$ for plains, $2.3 \mathrm{~m}$ for low hills, $3.8 \mathrm{~m}$ for high hills and low mountains, and $7.0 \mathrm{~m}$ for mountains (Podobnikar 2006, 25; Hrvatin \& Perko 2005, 9).

The IDRISI (Eastman 1995) and ArcGIS (McCoy \& Johnston 2001) software packages were used to carry out GIS calculations.

\section{Types of Hammond's landform units}

Hammond thus used three elements with four, six, and four classes, respectively, to define landform units; theoretically, this represents 96 combinations or 96 possible landform units. However, he only selected twenty-one units (i.e., a good fifth of all possible combination), which he grouped into five landform groups.

To simplify this, Hammond defined the units according to the elevation of hills or mountains, and the percentage and concavity (or convexity) of the terrain above which they rise.

The first group includes plains with the following four landform units:

- Flat plains: at least eighty percent of the terrain with a less than eight percent slope and relief below $30 \mathrm{~m}$ (labeled A1); 
- Smooth plains: at least eighty percent of the terrain with a less than eight percent slope and relief between 30 and $90 \mathrm{~m}$ (labeled A2);

- Irregular plains with slight relief: fifty to eighty percent of the terrain with a less than eight percent slope and relief below $30 \mathrm{~m}$ (labeled B1);

- Irregular plains: fifty to eighty percent of the terrain with a less than eight percent slope and relief between 30 and $90 \mathrm{~m}$ (labeled B2).

The second group includes tablelands with the following four units of predominant convex terrain:

- Tablelands with moderate relief: fifty to eighty percent of the terrain with a less than eight percent slope and relief between 90 and $150 \mathrm{~m}$ (labeled B3cd);

- Tablelands with considerable relief: fifty to eighty percent of the terrain with a less than eight percent slope and relief between 150 and $300 \mathrm{~m}$ (labeled B4cd);

- Tablelands with high relief: fifty to eighty percent of the terrain with a less than eight percent slope and relief between 300 and $900 \mathrm{~m}$ (labeled B5cd);

- Tablelands with very high relief: fifty to eighty percent of the terrain with a less than eight percent slope and relief between 900 and 1,500 $\mathrm{m}$ (labeled B6cd).

The third group includes plains with hills or mountains with the following four units of predominant concave terrain:

- Plains with hills: at least fifty percent of the terrain with a less than eight percent slope and relief between 90 and $150 \mathrm{~m}$ (labeled AB3ab);

- Plains with high hills: fifty to eighty percent of the terrain with a less than eight percent slope and relief between 150 and $300 \mathrm{~m}$ (labeled B4ab);

- Plains with low mountains: fifty to eighty percent of the terrain with a less than eight percent slope and relief between 300 and $900 \mathrm{~m}$ (labeled B5ab);

- Plains with high mountains: fifty to eighty percent of the terrain with a less than eight percent slope and relief between 900 and 1,500 $\mathrm{m}$ (labeled B6ab).

The fourth group includes open hills and mountains with the following five landform units:

- Open low hills: twenty to fifty percent of terrain with a less than eight percent slope and relief between 30 and $90 \mathrm{~m}$ (labeled C2);

- Open hills: twenty to fifty percent of terrain with a less than eight percent slope and relief between 90 and $150 \mathrm{~m}$ (labeled C3);

- Open high hills: twenty to fifty percent of terrain with a less than eight percent slope and relief between 50 and $300 \mathrm{~m}$ (labeled C4);

- Open low mountains: twenty to fifty percent of terrain with a less than eight percent slope and relief between 300 and $900 \mathrm{~m}$ (labeled C5);

- Open high mountains: twenty to fifty percent of terrain with a less than eight percent slope and relief between 300 and $900 \mathrm{~m}$ (labeled C6).

The fifth group includes hills and mountains with the following four landform units:

- Hills: less than twenty percent of terrain with a less than eight percent slope and relief between 90 and $150 \mathrm{~m}$ (labeled D3);

- High hills: less than twenty percent of terrain with a less than eight percent slope and relief between 150 and $300 \mathrm{~m}$ (labeled D4);

- Low mountains: less than twenty percent of terrain with a less than eight percent slope and relief between 300 and $900 \mathrm{~m}$ (labeled D5);

- High mountains: less than twenty percent of terrain with a less than eight percent slope and relief between 900 and 1,500 $\mathrm{m}$ (labeled D6).

\section{Hammond's landform units in Slovenia}

Of twenty-one landform units specified by Hammond, only thirteen were found in Slovenia. In plains, two units are missing, in tablelands three units are missing, and one unit each is missing in plains with hills and mountains, in open hills and mountains, and in hills and mountains.

In Slovenia, the following two units are included in the plains group:

- Flat plains, which cover half a percent of Slovenia's surface and lie entirely in Pannonian Slovenia, especially along the Mura River; 
- Smooth plains, which also cover half a percent of Slovenia's surface and lie almost entirely in Pannonian Slovenia, again especially along the Mura River.

The second landform unit group (i.e., tablelands) only includes one unit:

- Tablelands with moderate relief, which cover barely one percent of Slovenia's surface and lie entirely in Pannonian Slovenia (the Goričko area in the northeasternmost part of the country is this unit's most typical region).

The third landform unit group (i.e., plains with hills or mountains) includes three units:

- Plains with hills, which cover 3\% of Slovenia's terrain and lie almost entirely in Pannonian Slovenia, especially along the Mura and Drava rivers and the lower reaches of their major tributaries;

- Plains with high hills, which cover 5\% of Slovenia's terrain, with the majority lying in Pannonian Slovenia and just under 10\% in Dinaric Slovenia;

- Plains with low mountains, which cover just under $7 \%$ of Slovenia and lie primarily in the Alpine basins.

The fourth group (i.e., open hills or mountains) includes four units:

- Open hills, which cover just under a percent of Slovenia's surface and lie entirely in Pannonian Slovenia, the most typical being the Goričko and Slovenske Gorice areas;

- Open high hills, which cover 4\% of Slovenia's surface, with 80\% lying in Pannonian Slovenia and 20\% in Dinaric Slovenia and the most typical regions being Slovenske Gorice, Goričko, and Haloze;

- Open low mountains, which cover $20 \%$ of Slovenia's surface and constitute the most evenly distributed unit in the country, with just above one half lying in Dinaric Slovenia;

- Open high mountains, which cover $2 \%$ of Slovenia and the majority of them lie in Alpine Slovenia, especially the Ljubljana Basin.

The fifth landform unit group (i.e., hills or mountains) includes three units:

- High hills, which cover just under one percent of Slovenia's surface and lie entirely in Pannonian Slovenia (i.e., in the central part of the Goričko area);

- Low mountains, which cover $30 \%$ of Slovenia's surface and are relatively evenly distributed across Slovenia, with the majority of them lying in Alpine and Dinaric Slovenia and the most typical region being the Sava Valley Hills;

- High mountains, which cover 27\% of Slovenia's surface, with $80 \%$ lying in Alpine and 20\% in Dinaric Slovenia, and the most typical region being the Julian Alps.

It is interesting to see which landform units some of the major Slovenian regions include:

- The Pannonian low hills in the Goričko area in northeastern Slovenia: a good third of the region consists of open high hills, a third consists of high hills, a good tenth consists of plains with high hills, another tenth of open hills, and just under a tenth of plains with hills;

- The Mediterranean Karst plateau in the hinterland of Trieste in southwestern Slovenia: nearly 80\% of the region consists of open low mountains;

- The low Dinaric karst plain of White Carniola in southeastern Slovenia: just under half of the region consists of open low mountains, just under a quarter consists of plains with high hills, and a good fifth consists of open high hills;

- The extensive Sava Valley Hills to the east of Ljubljana: more than $80 \%$ of the region consists of low mountains;

- The plateau-like Pohorje Mountains to the west of Maribor: $80 \%$ of the region consists of high mountains, just above $10 \%$ consists of plains with low mountains, and just under $10 \%$ consists of low mountains;

- The Julian Alps in northwestern Slovenia: 99\% of the region consists of high mountains.

Given their actual morphological features, the last three Slovenian regions are classified relatively well following Hammond's method (i.e., into proper landform units), whereas the first three are classified more poorly.

\section{Adaptation of Hammond's method to Slovenia's surface characteristics}

Due to weaknesses that were revealed in the classification of Slovenia's surface following Hammond's original method, we decided to adapt the method correspondingly. The basic $10 \times 10 \mathrm{~km}$ square window is 


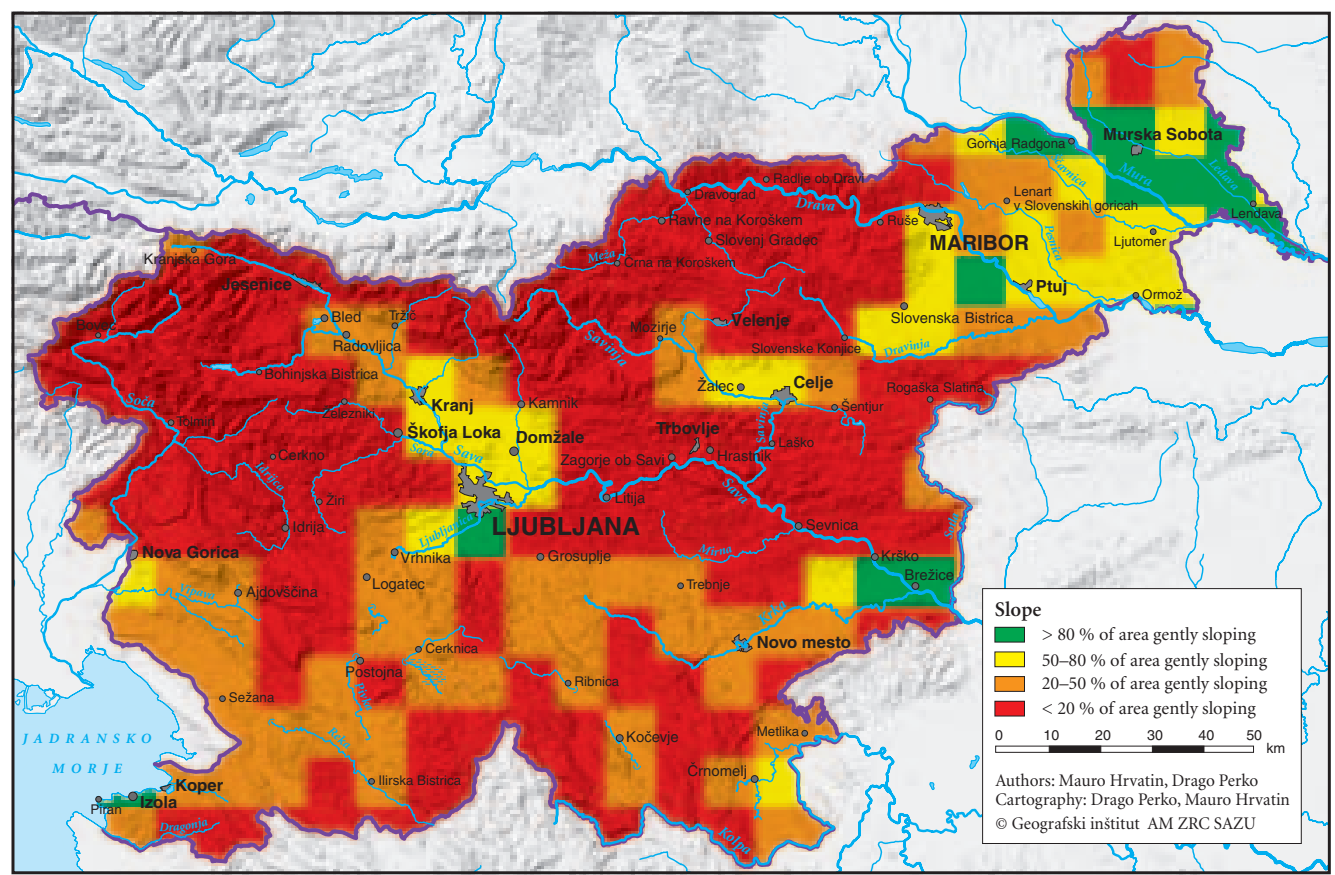

Figure 1: Hammond's first element: slope.

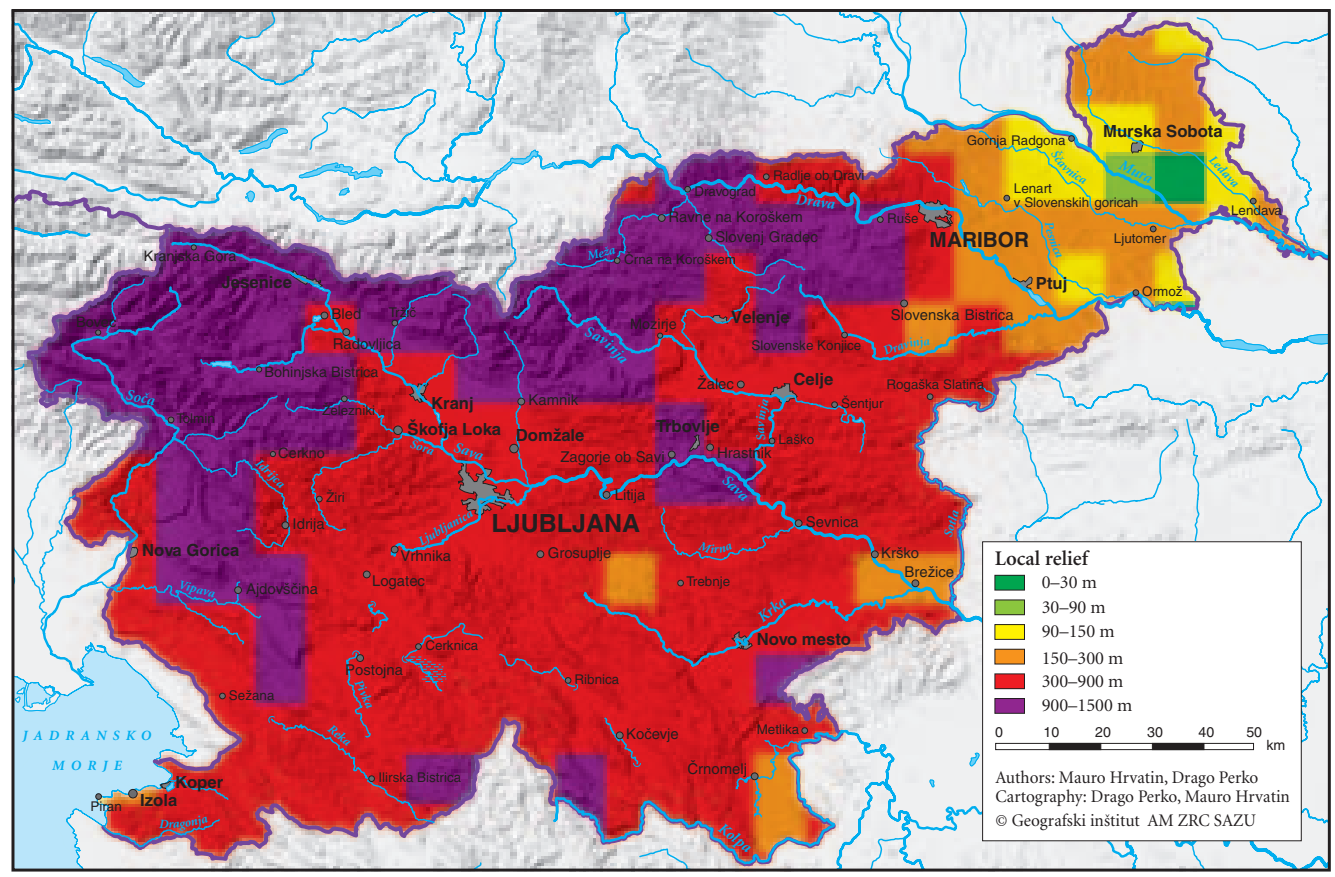

Figure 2: Hammond's second element: local relief. 


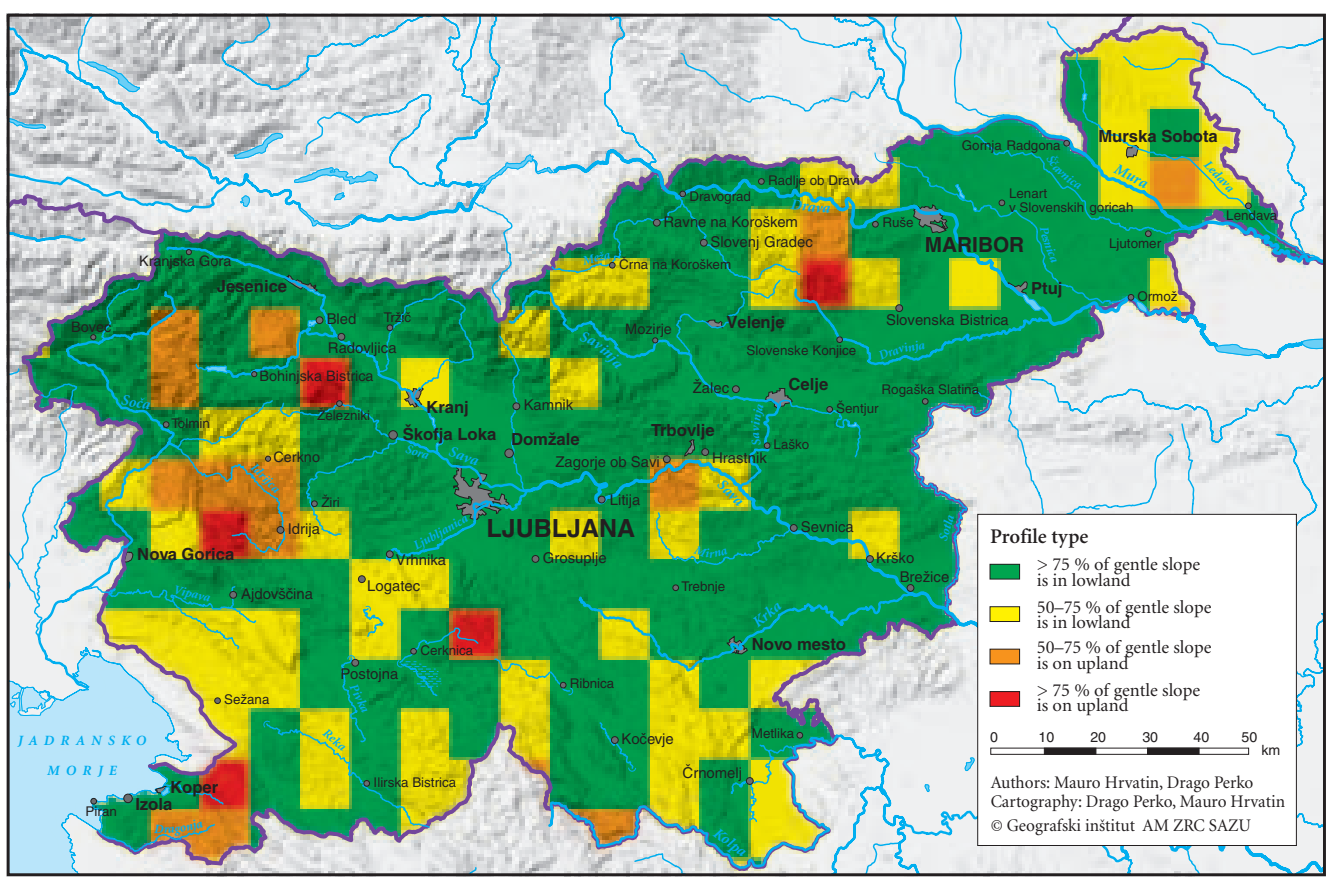

Figure 3: Hammond's third element: profile type.

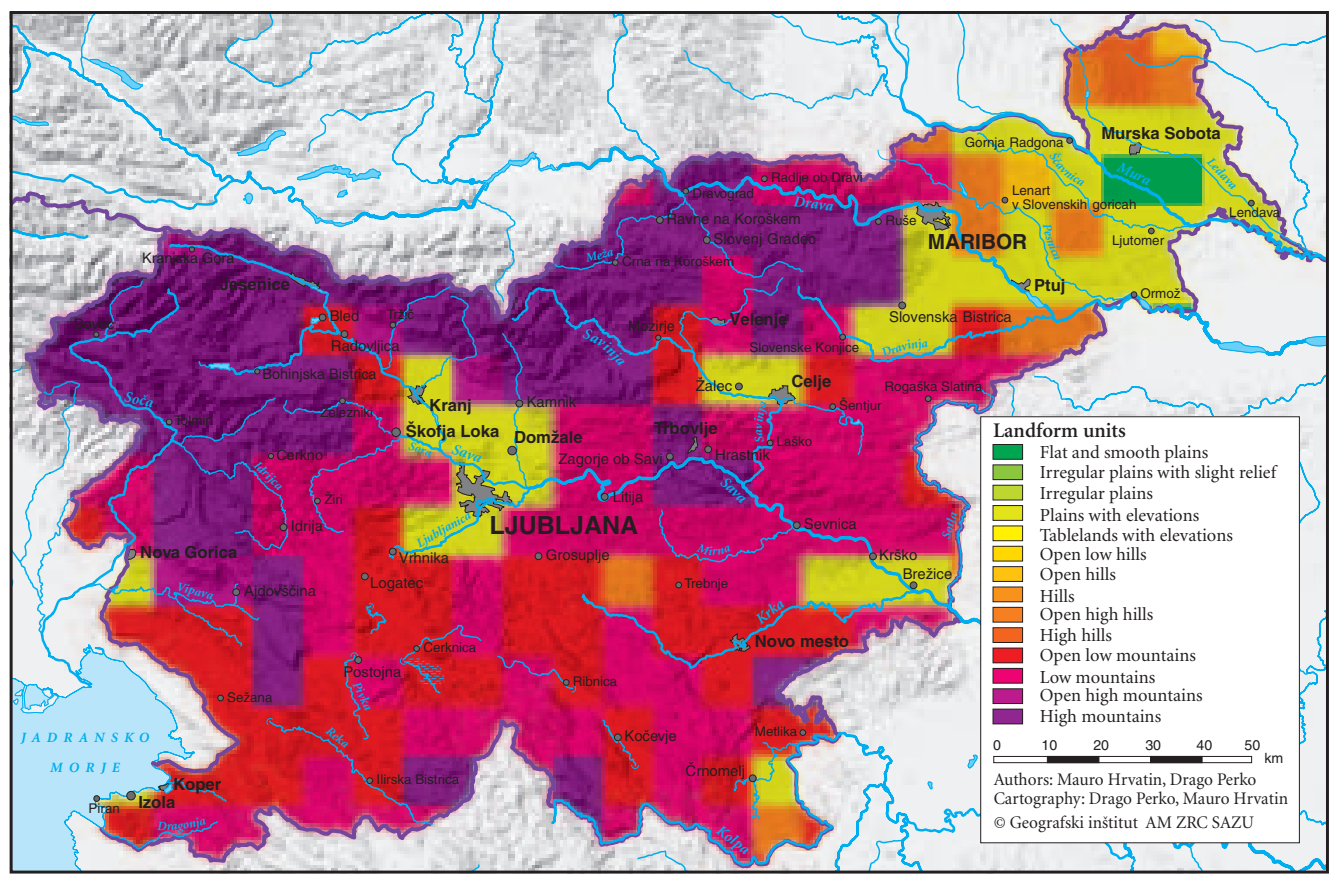

Figure 4: Hammond's original landform units in Slovenia. 
Figure 5: Hammond's adapted landform units in Slovenia.

considerably too large for Slovenia, which has a small territory but extremely diverse relief and a wide range of geomorphologic processes (Zorn \& Komac 2004; Zorn \& Komac 2007; Hrvatin \& Perko 2008).

Even the window's square form is not really the most suitable because in a square the points on the edges are not equidistant from the focal point. With the adapted method we thus decided to use a basic window in the form of a circle, the size of which approximates a square kilometer. Given that the calculations were carried out on a 25-meter digital elevation model, a circle with a radius of 23 units or $575 \mathrm{~m}$ and an area of $1.03 \mathrm{~km}^{2}$ was selected. Each cell defined this way included 1,653 DEM points.

With Hammond's original method, the basic square windows follow one another with no overlaps; however, we decided to use a more accurate method, in which the basic circle cell partially overlapped with the 25-meter increment.

The range of individual classes also had to be adapted. With the first element, the percentages of gently sloping terrain were modified as follows:

- A: $>99 \%$ gently sloping terrain,

- B: $50-99 \%$ gently sloping terrain,

- C: $1-50 \%$ gently sloping terrain,

- D: $<1 \%$ gently sloping terrain.

With the second element, the elevation difference was modified as follows:

- 1: 0-50 m,

- 2: $50-100 \mathrm{~m}$,

- 3: $100-200 \mathrm{~m}$,

- 4: $200-300 \mathrm{~m}$,

- 5: 300-400 m,

- 6: $400 \mathrm{~m}$ and more.

The new class boundaries of the first and second elements were specified empirically by testing several times how individual changes in the class boundaries approximate the actual conditions in the region (Hrvatin \& Perko 2009). Other authors of similar classifications have also had to adapt Hammond's method to the relief characteristics of specific regions (Dikau 1991; Brabyn 1998; Gallant et al. 2005).

In naming the landform units, problems occur with the semantic differences between the English and Slovenian terms referring to hills and mountains, which is why these terms had to be suitably adapted as well (Table 1).

Table 1: Approximate equivalent of English and Slovenian terms according to surface height differences.

\begin{tabular}{lll}
\hline Local relief & English term for elevations & Slovenian term for elevations \\
\hline $0-30 \mathrm{~m}$ & plains & ravnine \\
$50-100 \mathrm{~m}$ & low hills & nizki griči \\
$100-200 \mathrm{~m}$ & hills & visoki griči \\
$200-300 \mathrm{~m}$ & high hills & nizki hribi \\
$300-900 \mathrm{~m}$ & low mountains & visoki hribi \\
$900-1500 \mathrm{~m}$ & high mountains & gore \\
\hline
\end{tabular}

\section{Conclusion}

Hammond's method proved to be of relatively high quality in classifying landforms in the United States. However, in the case of Slovenia, where the morphological characteristics of the surface change rapidly, this method is not sufficiently accurate. A number of Slovenian regions are thus classified under units that do not reflect their actual morphological characteristics because, due to the size of the basic square window, the morphological characteristics of the neighboring regions are also taken into account. The basic square window with an area of nearly $100 \mathrm{~km}^{2}$ is considerably too large for determining all three of Hammond's elements.

Hammond's method thus proves more successful in classifying morphologically extensive and relatively uniform regions; however, recent studies (Dikau 1991; Brabyn 1998; Gallant et al. 2005) demonstrate 


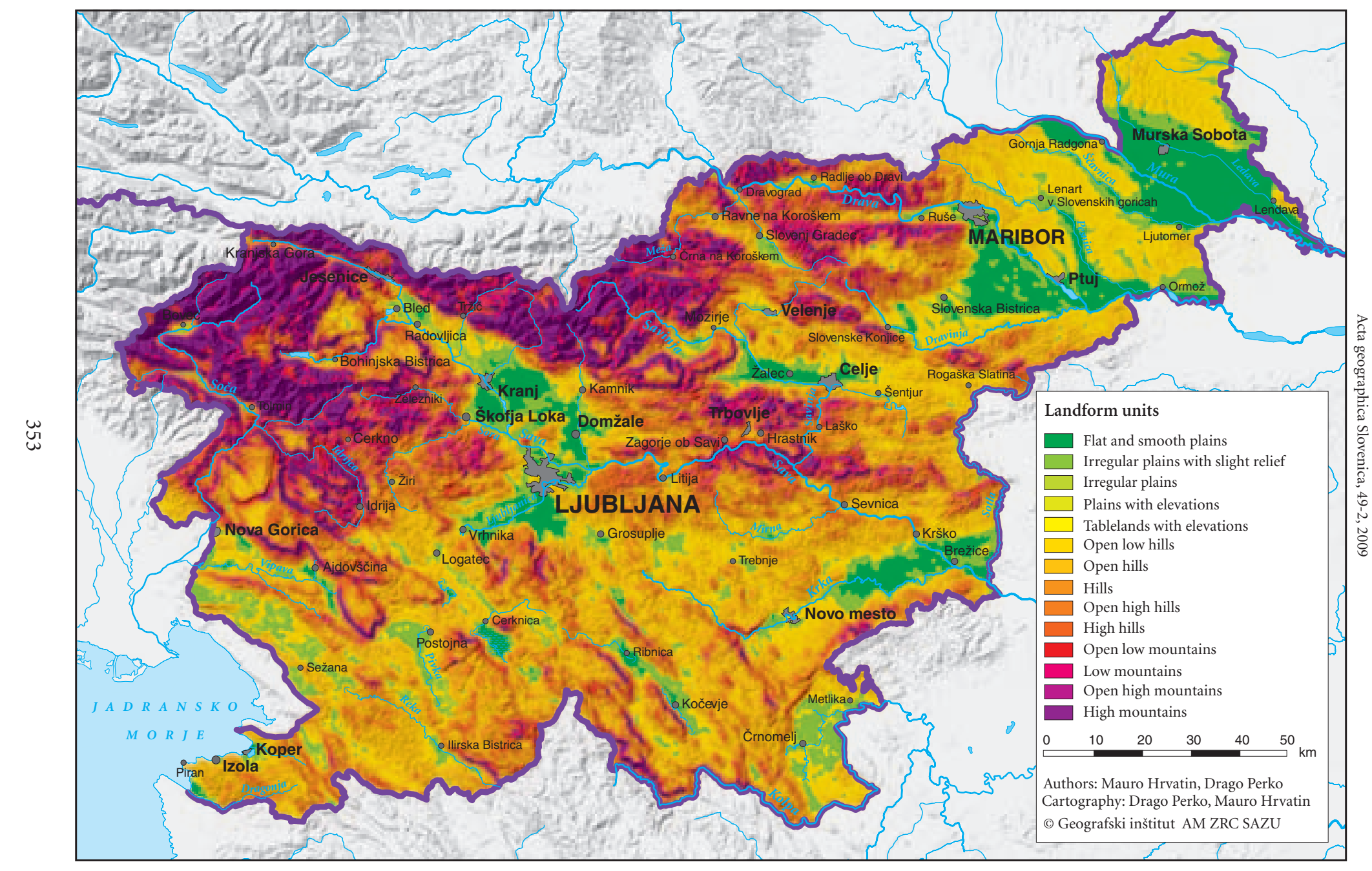


that it can also be successful in classifying morphologically diverse regions if it is suitably adapted. The method can be adapted to a region's morphological characteristics by changing the form and size of the basic cell and the class boundaries of the classification elements. Using this kind of adapted method, nineteen landform units were identified in Slovenia (Hrvatin \& Perko 2009).

According to Hammond's original method, two thirds of Slovenia consists of hills and low mountains, just under a third consists of high mountains, barely four percent consists of low hills, and not even one percent consists of flat plains. However, according to Hammond's adapted method, more than two fifths of Slovenia consists of low hills, just under a third consists of hills, a good tenth consists of high mountains, and just under a tenth consists of flat plains (Table 2).

Table 2: Comparison between Hammond's original and adapted landform units in Slovenia.

\begin{tabular}{|c|c|c|c|c|c|}
\hline \multirow[t]{2}{*}{ Landform unit } & \multicolumn{2}{|c|}{ Original unit } & \multicolumn{2}{|c|}{ Adapted unit } & \multirow{2}{*}{$\begin{array}{c}\text { Ratio between original (0) } \\
\text { and adapted (A) units }\end{array}$} \\
\hline & ha & $\%$ & ha & $\%$ & \\
\hline Flat plains & $9,981.16$ & 0.49 & $139,524.13$ & 6.88 & 0.07 \\
\hline Smooth plains & $9,337.93$ & 0.46 & 0.00 & 0.00 & - \\
\hline Irregular plains with slight relief & 0.00 & 0.00 & $142,485.71$ & 7.03 & 0.00 \\
\hline Irregular plains & 0.00 & 0.00 & $93,131.54$ & 4.59 & 0.00 \\
\hline Tablelands with moderate relief & 193.21 & 0.01 & $1,116.62$ & 0.06 & 0.17 \\
\hline Tablelands with considerable relief & 0.00 & 0.00 & 37.37 & 0.00 & 0.00 \\
\hline Tablelands with high relief & 0.00 & 0.00 & 3.50 & 0.00 & 0.00 \\
\hline Tablelands with very high relief & 0.00 & 0.00 & 0.00 & 0.00 & - \\
\hline Plains with hills & $60,933.96$ & 3.01 & $18,939.92$ & 0.93 & 3.22 \\
\hline Plains with high hills & $110,547.32$ & 5.45 & $1,550.15$ & 0.08 & 71.31 \\
\hline Plains with low mountains & $137,072.88$ & 6.76 & 210.51 & 0.01 & 651.13 \\
\hline Plains with high mountains & 0.00 & 0.00 & 62.36 & 0.00 & 0.00 \\
\hline Open low hills & 0.00 & 0.00 & $249,580.81$ & 12.31 & 0.00 \\
\hline Open hills & $14,140.83$ & 0.70 & $539,664.56$ & 26.62 & 0.03 \\
\hline Open high hills & $81,976.40$ & 4.04 & $319,033.14$ & 15.74 & 0.26 \\
\hline Open low mountains & $398,932.95$ & 19.68 & $116,088.67$ & 5.73 & 3.44 \\
\hline Open high mountains & $41,094.11$ & 2.03 & $67,725.60$ & 3.34 & 0.61 \\
\hline Hills & 0.00 & 0.00 & $1,697.36$ & 0.08 & 0.00 \\
\hline High hills & $14,720.70$ & 0.73 & $54,580.41$ & 2.69 & 0.27 \\
\hline Low mountains & $600,192.86$ & 29.61 & $100,372.14$ & 4.95 & 5.98 \\
\hline High mountains & $548,167.93$ & 27.04 & $181,487.74$ & 8.95 & 3.02 \\
\hline Total & $2,027,292.25$ & 100.00 & $2,027,292.25$ & 100.00 & 1.00 \\
\hline
\end{tabular}

\section{References}

Brabyn, L. 1998: GIS analysis of macro landform. $10^{\text {th }}$ colloquium of the Spatial Information Research Centre, University of Otago. Dunedin.

Digitalni model višin 25. Geodetska uprava Republike Slovenije. Zbirka podatkov. Ljubljana. 2005.

Dikau, R., Brabb, E. E., Mark, R. K. 1991: Landform classification of New Mexico by computer. U. S. Department Interior, U.S. Geological Survey. Menlo Park.

Eastman, J. R. 1995: IDRISI for Windows. User's Guide. Worcester.

Gabrovec, M., Hrvatin, M. 1998: Površje. Geografski atlas Slovenije. Ljubljana.

Gallant, A. L., Douglas, D. B., Hoffer, R. M. 2005: Automated mapping of Hammond's landforms. IEEE geoscience and remote sensing letters 2-4. Piscataway.

Geografija. Zbirka Tematski leksikoni. Tržič 2001.

Hammond, E. H. 1954: Small scale continental landform maps. Annals of Association of American Geographers 44. Washington.

Hammond, E. H. 1964: Analysis of properties in landform geography: An application to broadscale landform mapping. Annals of Association of American Geographers 54. Washington.

Hrvatin, M., Perko, D. 2005: Differences between 100-m and 25-m digital elevation models according to relief types in Slovenia. Acta geographica Slovenica 45-1. Ljubljana. doi: 10.3986/AGS45101 
Hrvatin, M., Perko, D. 2008: Landscape characteristics of common land in Slovenia. Acta geographica Slovenica 48-1. Ljubljana. doi: 10.3986/AGS48101

Perko, D., Hrvatin, M. 2009: Določanje enot oblikovanosti površja v Sloveniji s prirejeno Hammondovo metodo. Geografski vestnik 81-2. Ljubljana.

Iwahashi, J., Pike, R.J. 2006: Automated classifications of topography from DEMs by an unsupervised nested-means algorithm and a three-part geometric signature. Geomorphology 86. Amsterdam. doi:10.1016/ j.geomorph.2006.09.012

McCoy, J., Johnston, K. 2001: Using ArcGIS Spatial Analyst. Redlands.

Melik, A. 1935: Slovenija. Geografski opis. Ljubljana.

Natek, K. 1993: Tipi površja v Sloveniji 1. Geografski obzornik 40-4. Ljubljana.

Perko, D. 1992: Zveze med reliefom in gibanjem prebivalstva 1880-1981 v Sloveniji. Doktorska disertacija. Ljubljana.

Perko, D. 2001: Analiza površja Slovenije s stometrskim digitalnim modelom reliefa. Geografija Slovenije 3. Ljubljana.

Perko, D. 2007: Morfometrija površja Slovenije. Georitem 3. Ljubljana.

Perko, D. 2009: Morfometrični kazalniki enot oblikovanosti površja v Sloveniji. Geografski vestnik 81-1. Ljubljana.

Perko, D., Hrvatin, M. 2009: Določanje enot oblikovanosti površja v Sloveniji s prirejeno Hammondovo metodo. Geografski vestnik 81-2. Ljubljana.

Podobnikar, T. 2002: Koncept izdelave novega digitalnega modela reliefa Slovenije. Geografski vestnik 74-1. Ljubljana.

Podobnikar, T. 2005: Production of integrated digital terrain model from multiple datasets of different quality. International Journal of Geographical Information Science 19-1. London. doi: 10.1080/ 13658810412331280130

Podobnikar, T. 2006: Digitalni model reliefa iz različnih podatkov. Življenje in tehnika 57-4. Ljubljana.

Zorn, M., Komac, B. 2004: Deterministic modeling of landslide and rockfall risk. Acta geographica Slovenica 44-2. Ljubljana. doi: 10.3986/AGS44203

Zorn, M., Komac, B. 2007: Probability modeling of landslide hazard. Acta geographica Slovenica 47-2. Ljubljana. DOI: 10.3986/AGS47201 


\section{Primernost Hammondove metode za določanje enot oblikovanosti površja v Sloveniji}

DOI: $10.3986 / A G S 49204$

UDK: 911.2:551.43(497.4)

COBISS: 1.01

IZVLEČEK: Oblikovanost površja je pogosto najpomembnejši dejavnik razlikovanja med pokrajinami in pomembna prvina pri geografskih klasifikacijah, tipizacijah in regionalizacijah, zato imajo morfološke delitve površja v tujini in pri nas že dolgo tradicijo. Eno izmed najbolj znanih klasifikacij je izdelal ameriški geograf Edwin H. Hammond, ki je podrobno razčlenil površje Združenih držav Amerike. Njegovo metodo so kasneje s pomočjo geografskega informacijskega sistema in digitalnega modela višin še večkrat uporabili. Računalniške členitve površja so postale bolj objektivne, izbor klasifikacijskih prvin in njihovih razredov pa je ostal subjektiven.

Hammondova metoda določanja enot oblikovanosti površja je poznana po vsem svetu, zato smo jo preizkusili tudi na primeru Slovenije. Najprej smo upoštevali izvirne klasifikacijske prvine in od $21 \mathrm{Ham}-$ mondovih enot oblikovanosti površja v Sloveniji izluščili le 13. Zaradi slabosti, ki so se pri tem pokazale, smo izvirno Hammondovo metodo ustrezno priredili. Spremenili smo obliko in velikost temeljne celice ter meje razredov klasifikacijskih prvin. S prirejeno metodo smo v Sloveniji določili 19 enot oblikovanosti površja.

KLJUČNE BESEDE: geomorfologija, enota oblikovanosti površja, Hammondova metoda, geografski informacijski sistem, digitalni model višin, Slovenija

Uredništvo je prejelo prispevek 5. oktobra 2009.

NASLOVI:

\section{Mauro Hrvatin}

Geografski inštitut Antona Melika

Znanstvenoraziskovalni center Slovenske akademije znanosti in umetnosti

Gosposka ulica 13, SI - 1000 Ljubljana, Slovenija

E-pošta: mauro@zrc-sazu.si

\section{dr. Drago Perko}

Geografski inštitut Antona Melika

Znanstvenoraziskovalni center Slovenske akademije znanosti in umetnosti

Gosposka ulica 13, SI - 1000 Ljubljana, Slovenija

E-pošta: drago@zrc-sazu.si

\section{Vsebina}

1 Uvod 357

2 Opis Hammondove metode 358

3 Vrste Hammondovih enot oblikovanosti 359

Enote oblikovanosti površja v Sloveniji
po Hammondovi metodi

Prilagoditev Hammondove metode
značilnostim površja v Sloveniji

6 Sklep 364

7 Viri in literatura 366 


\section{Uvod}

V reliefno razgibani Sloveniji je oblikovanost površja pogosto najpomembnejši dejavnik razlikovanja med pokrajinami in pomembna prvina pri geografskih klasifikacijah, tipizacijah in regionalizacijah (Perko 2001; Perko 2007), zato so slovenski geografi izdelali že več delitev ozemlja glede na relief.

Najstarejšo reliefno tipizacijo je izdelal Melik, ki je na geomorfološki karti slovenskega ozemlja ločil kar 16 enot oblikovanosti površja (Melik 1935):

- visoko gorovje,

- sredogorje z visokogorskimi grebeni,

- sredogorje,

- hribovje,

- nizko hribovje,

- vzpetine v apniško-škriljevem zemljišču panonsko-rodopske cone nad $550 \mathrm{~m}$,

- vzpetine v apniško-škriljevem zemljišču panonsko-rodopske cone pod $550 \mathrm{~m}$,

- planote $\mathrm{v}$ apniškem zemljišču $\mathrm{v}$ višini nad $400 \mathrm{~m}$,

- planote $\mathrm{v}$ apniškem zemljišču v višini pod $400 \mathrm{~m}$,

- hribovje v flišnem zemljišču v Primorju,

- gričevje v flišnem zemljišču v Primorju,

- hribovje v starejšem terciarnem zemljišču na panonski strani,

- hribovje v mlajšem terciarnem zemljišču na panonski strani,

- gričevje s hribi v kotlinah ter podolja v dinarskem predelu,

- večje starodiluvijalne terase v subpanonskem področju,

- ravnine.

Sredogorje z visokogorskimi grebeni, sredogorje, hribovje in nizko hribovje je Melik razčlenil še podrobneje, in sicer glede na kamninsko sestavo posamezne enote. Omeniti velja, da geomorfološka karta ni povsem skladna z njenim opisom. V opisu je na primer zapisano, da je gričevje v najširšem obsegu zastopano $\mathrm{v}$ subpanonskem delu, na zemljevidu pa so gričevja vrisana le v sredozemskem delu.

Novo reliefno tipizacijo Slovenije je po dolgem časovnem presledku pripravil Natek, ki je ločil 8 tipov površja (Natek 1993):

- ravnine (raven svet z reliefno amplitudo do $30 \mathrm{~m}$, večinoma v fluvialnih in fluvio-glacialnih naplavinah),

- gričevja (slemenasto-dolinasto površje z reliefno amplitudo od 30 do 200 m, večinoma v miocensko-pliocenskih kamninah),

- hribovja (slemenasto-dolinasto površje z reliefno amplitudo nad $200 \mathrm{~m}$ do zgornje gozdne meje),

- visokogorje (svet nad zgornjo gozdno mejo, večinoma visokogorski kras),

- nizki kras (večinoma uravnano oziroma nizke vzpetine in vmesne globeli v relativno nižjih legah kot soseščina),

- visoki kras (visoke planote in hribovja z reliefno amplitudo prek $200 \mathrm{~m}$, slemenitvijo v dinarski smeri in vmesnimi kraškimi globelmi),

- nizki fluviokras (kraški svet s prevlado fluvio-denudacijskih površinskih oblik v relativno nižjih legah kot soseščina),

- visoki fluviokras (večinoma hribovja $\mathrm{v}$ dolomitu s prevlado fluvio-denudacijskih oblik).

Prvo računalniško zasnovano tipizacijo je v svoji doktorski disertaciji opravil Perko, ki je slovensko ozemlje razčlenil na 8 enot razgibanosti površja (Perko 1992; Perko 2001):

- nerazgibane ravnine,

- razgibane ravnine,

- nerazgibana gričevja,

- razgibana gričevja,

- nerazgibana hribovja,

- razgibana hribovja,

- gorovja,

- velike doline.

Razgibanost površja je določil s pomočjo reliefnega koeficienta. Ta je geometrična sredina višinskega koeficienta in naklonskega koeficienta, ki slonita na prostorskem spreminjanju nadmorskih višin in naklonov površja. V geografskem informacijskem sistemu je nato z večkratnim filtriranjem sloja z reliefnimi koeficienti 
dobil enotna območja istega morfološkega razreda, ki jih je poimenoval morfološke enote (Perko 2001). Kasneje je na podoben način določal morfološke enote na temelju višinskega koeficienta in ekspozicijskega koeficienta, ki slonita na prostorskem spreminjanju nadmorskih višin in ekspozicij površja, in skupnega koeficienta, ki je geometrična sredina prvih dveh (Perko 2007; Perko 2009).

$\mathrm{Za}$ Geografski atlas Slovenije sta svojo členitev pripravila Gabrovec in Hrvatin. Slovenijo sta razdelila na 6 reliefnih enot in ločila (Gabrovec in Hrvatin 1998):

- ravnine (nižja uravnana območja),

- gričevja (območja, ki imajo do $300 \mathrm{~m}$ višinske razlike med slemeni in dolinami),

- hribovja (območja, ki imajo od 300 do 1000 m višinske razlike med slemeni in dolinami),

- gorovja (območja, ki segajo z vrhovi in grebeni nad gozdno mejo, oziroma nad $1700 \mathrm{~m}$ ),

- nizke planote (višja uravnana območja do nadmorske višine $700 \mathrm{~m}$ ),

- visoke planote (višja uravnana območja nad 1000 m nadmorske višine).

Tudi v svetu imajo morfološke tipizacije površja že večdesetletno tradicijo. Eno najbolj znanih klasifikacij je opravil ameriški geograf Edwin H. Hammond, ki se je najprej lotil reliefne členitve Severne in Južne Amerike na zemljevidih v malih merilih (Hammond 1954). Ozemlji obeh celin je razdelil na kvadrate z osnovnico 7,5 minut zemljepisne dolžine in zemljepisne širine, nato pa za vsak kvadrat ugotovil maksimalno višinsko razliko, delež ravnega sveta z naklonom do $8 \%$ ter delež ravnega sveta, ki se pojavlja v nižinah. Na temelju zadnje prvine je ločil ravnine, pri katerih je večina ravnega sveta v nižinah, od planot, pri katerih je večina ravnega sveta $\mathrm{v}$ višinah.

S kombiniranjem vseh treh prvin je nato površje celin razdelil na 8 enot:

- prave ravnine,

- nepravilne ravnine,

- ravnine z vzpetinami,

- planote,

- gričevja,

- hribovja,

- gorovja,

- ledeni pokrovi.

Bolj odmevna je bila Hammondova podrobna klasifikacija površja Združenih držav Amerike (Hammond 1964). Kasneje so njegovo metodo večkrat uporabili ob podpori računalnikov in digitalnega modela višin. Prvi, ki je uspešno prenesel Hammondovo metodo v računalniški algoritem, je bil Dikau pri členitvi Nove Mehike (Dikau 1991), sledila pa sta mu še Brabyn na Novi Zelandiji (Brabyn 1998) in Gallantova na Aljaski (Gallant s sodelavci 2005).

Dolgotrajne in zamudne klasifikacije oblikovanosti površja na temelju zemljevidov so tako nadomestile hitrejše in natančnejše členitve $\mathrm{z}$ računalniško podprtim geografskim informacijskim sistemom. Tovrstne klasifikacije so bolj objektivne, čeprav sta izbor klasifikacijskih prvin in izbor njihovih razredov še naprej subjektivna. Iwahashi in Pike sta pripravila pregled dvanajstih klasifikacij oblikovanosti površja, ki so bile objavljene v zadnjih letih, in prav vse so bile izdelane s pomočjo računalnika (Iwahashi in Pike 2006).

\section{Opis Hammondove metode}

Pri podrobni klasifikaciji oblikovanosti površja Združenih držav Amerike je Hammond kot temeljno površinsko enoto za računanje reliefnih prvin uporabil kvadratno celico z osnovnico 6 milj, kar je približno $9,65 \mathrm{~km}$, in površino $93,12 \mathrm{~km}^{2}$, kar se morda zdi veliko, v okvirih Združenih držav Amerike pa obsega le slabo stotisočinko ozemlja. Celice so si sledile ena za drugo brez medsebojnega prekrivanja. S pomočjo zemljevidov v merilu $1: 250.000$ je v vsaki celici ugotavljal tri prvine: naklon, krajevno višinsko razliko in vrsto prereza. Vsako prvino je označil z dogovorjenim znakom, z njihovimi kombinacijami pa je določil enote oblikovanosti površja.

Prva prvina Hammondove klasifikacije je naklon. Za vsako celico je ugotovil, kolikšen delež njene površine ima naklon manjši od $8 \%$, kar je približno $4,57^{\circ}$. Dogovorjeni znak, s katerim je označil to prvino, je velika črka:

- A: $>80 \%$ površja je rahlo nagnjenega,

- B: $50-80 \%$ površja je rahlo nagnjenega, 
- C: $20-50 \%$ površja je rahlo nagnjenega,

- D: $<20 \%$ površja je rahlo nagnjenega.

Druga prvina Hammondove klasifikacije je krajevna višinska razlika. Za vsako celico je ugotovil maksimalno in minimalno nadmorsko višino ter izračunal njuno razliko. Dogovorjeni znak, s katerim je označil to prvino, je števka:

- 1: 0-30 m,

- 2: 30-90 m,

- 3: $90-150 \mathrm{~m}$,

- 4: 150-300 m,

- 5: 300-900 m,

- 6: $900-1500 \mathrm{~m}$.

Tretja prvina Hammondove klasifikacije je vrsta prereza. Za vsako celico je ugotovil, kolikšen delež rahlo nagnjenega površja leži pod ali nad povprečno nadmorsko višino celice. Dogovorjeni znak, s katerim je označil to prvino, je mala črka:

- a: $>75 \%$ rahlo nagnjenega površja je v nižavju,

- b: 50-75\% rahlo nagnjenega površja je v nižavju,

- c: $50-75 \%$ rahlo nagnjenega površja je v višavju,

- $\mathrm{d}:>75 \%$ rahlo nagnjenega površja je v višavju.

S kombiniranjem predstavljenih prvin je Hammond določil enote oblikovanosti površja. Vrisal jih je na velik barvni zemljevid v merilu $1: 5.000 .000$. Rezultate klasifikacije pa ni predstavili v obliki kvadratov, temveč z mejami enot oblikovanosti površja, ki jih je določil subjektivno in sledil obrobju ravnin, planot, hribovij in podobnih velikih reliefnih oblik. Zemljevid je zaradi tega sicer nekoliko posplošen, vendar bolj pregleden.

Ker je Hammondova metoda določanja enot oblikovanosti površja poznana po vsem svetu, smo se odločili, da jo preizkusimo tudi na primeru Slovenije. Pri tem smo upoštevali izvirne klasifikacijske prvine in njihove razrede. Kot podatkovni vir smo namesto zemljevida v merilu $1: 250.000$ uporabili petindvajsetmetrski digitalni model višin, zato je vsaka temeljna kvadratna celica vključevala kar 148.996 točk.

Petindvajsetmetrski digitalni model višin smo leta 2005 izdelali na Znanstvenoraziskovalnem centru Slovenske akademije znanosti in umetnosti za Geodetsko upravo Republike Slovenije (Podobnikar 2002; Podobnikar 2005; Podobnikar 2006). Sestavljajo ga podatki o nadmorskih višinah točk, ki so od severa proti jugu oziroma od vzhoda proti zahodu oddaljene $25 \mathrm{~m}$ in so oglišča kvadratnih celic z osnovnico $25 \mathrm{~m}$, diagonalo $35 \mathrm{~m}$ in površino $625 \mathrm{~m}^{2}$ (Digitalni ... 2005). Testiranje je pokazalo, da je njegova natančnost za celo Slovenijo 3,2 m: za ravnine $1,1 \mathrm{~m}$, za gričevja $2,3 \mathrm{~m}$, za hribovja $3,8 \mathrm{~m}$ in za gorovja 7,0 $\mathrm{m}$ (Podobnikar 2006, 25; Hrvatin in Perko 2005, 9).

Za izračune s pomočjo geografskega informacijskega sistema smo uporabili programska paketa IDRISI (Eastman 1995) in ArcGIS (McCoy in Johnston 2001).

\section{Vrste Hammondovih enot površja}

Hammond je za določanje enot oblikovanosti površja torej uporabil 3 prvine s štirimi, šestimi in še enkrat štirimi razredi, kar teoretično pomeni 96 kombinacij oziroma 96 možnih enot oblikovanosti površja. Dejansko se je odločil le za 21 enot, torej dobro petino možnih kombinacij, ki jih je združil v 5 skupin.

Poenostavljeno rečeno je enote določil glede na višino vzpetin ter delež in konkavnost oziroma konveksnost površja, iznad katerega se dvigajo.

Prva skupina so ravnine s štirimi enotami oblikovanosti površja. To so:

- ravne ravnine, kjer ima vsaj štiri petine površja naklon manjši od $8 \%$, višinske razlike pa so manjše od $30 \mathrm{~m}$ (oznaka A1),

- nagnjene ravnine, kjer ima prav tako vsaj štiri petine površja naklon manjši od $8 \%$, višinske razlike pa so med 30 in $90 \mathrm{~m}$ (oznaka A2),

- rahlo gričevnate ravnine, kjer ima polovica do štiri petine površja naklon manjši od $8 \%$, višinske razlike pa so manjše od $30 \mathrm{~m}$ (oznaka B1),

- močno gričevnate ravnine, kjer ima polovica do štiri petine površja naklon manjši od $8 \%$, višinske razlike pa so med 30 in 90 (oznaka B2). 
Druga skupina so planote s štirimi enotami prevladujočega izbočenega površja. To so:

- planote z griči, kjer ima polovica do štiri petine površja naklon manjši od $8 \%$, višinske razlike pa so med 90 in $150 \mathrm{~m}$ (oznaka B3cd),

- planote z nizkimi hribi, kjer ima polovica do štiri petine površja naklon manjši od $8 \%$, višinske razlike pa so med 150 in $300 \mathrm{~m}$ (oznaka B4cd),

- planote z visokimi hribi, kjer ima polovica do štiri petine površja naklon manjši od $8 \%$, višinske razlike pa so med 300 in $900 \mathrm{~m}$ (oznaka B5cd) in

- planote z gorami, kjer ima polovica do štiri petine površja naklon manjši od $8 \%$, višinske razlike pa so med 900 in $1500 \mathrm{~m}$ (oznaka B6cd).

Tretja skupina so ravnine z vzpetinami s štirimi enotami prevladujočega vbočenega površja. To so:

- ravnine z griči, kjer ima vsaj polovica površja naklon manjši od $8 \%$, višinske razlike pa so med 90 in $150 \mathrm{~m}(\mathrm{AB} 3 \mathrm{ab})$,

- ravnine z nizkimi hribi, kjer ima polovica do štiri petine površja naklon manjši od $8 \%$, višinske razlike pa so med 150 in $300 \mathrm{~m}$ (oznaka B4ab),

- ravnine z visokimi hribi, kjer ima polovica do štiri petine površja naklon manjši od $8 \%$, višinske razlike pa so med 300 in $900 \mathrm{~m}$ (oznaka B5ab) in

- ravnine z gorami, kjer ima polovica do štiri petine površja naklon manjši od $8 \%$, višinske razlike pa so med 900 in $1500 \mathrm{~m}$ (oznaka B6ab).

Četrta skupina so vzpetine z ravninami s petimi enotami oblikovanosti površja. To so:

- nizka gričevja z ravninami, kjer ima petina do polovica površja naklon manjši od $8 \%$, višinske razlike pa so med 30 in $90 \mathrm{~m}$ (oznaka C2),

- visoka gričevja z ravninami, kjer ima petina do polovica površja naklon manjši od $8 \%$, višinske razlike pa so med 90 in 150 m (oznaka C3),

- nizka hribovja z ravninami, kjer ima petina do polovica površja naklon manjši od $8 \%$, višinske razlike pa so med 150 in $300 \mathrm{~m}$ (oznaka C4),

- visoka hribovja z ravninami, kjer ima petina do polovica površja naklon manjši od $8 \%$, višinske razlike pa so med 300 in $900 \mathrm{~m}$ (oznaka C5) in

- gorovja z ravninami, kjer ima petina do polovica površja naklon manjši od $8 \%$, višinske razlike pa so med 900 in $1500 \mathrm{~m}$ (oznaka C6).

Peta skupina so vzpetine s štirimi enotami oblikovanosti površja. To so:

- gričevja, kjer ima manj kot petina površja naklon manjši od $8 \%$, višinske razlike pa so med 90 in $150 \mathrm{~m}$ (oznaka D3),

- nizka hribovja, kjer ima manj kot petina površja naklon manjši od $8 \%$, višinske razlike pa so med 150 in $300 \mathrm{~m}$ (oznaka D4),

- visoka hribovja, kjer ima manj kot petina površja naklon manjši od $8 \%$, višinske razlike pa so med $300 \mathrm{~m}$ in $900 \mathrm{~m}$ (oznaka D5) in

- gorovja, kjer ima manj kot petina površja naklon manjši od $8 \%$, višinske razlike pa so med $900 \mathrm{~m}$ in $1500 \mathrm{~m}$ (oznaka D6).

\section{Enote površja v Sloveniji po Hammondovi metodi}

Od 21 Hammondovih enot oblikovanosti površja smo jih v Sloveniji našli le 13. Pri ravninah manjkata 2 enoti, pri planotah 3 enote, pri ravninah z vzpetinami 1 enota, pri vzpetinah z ravninami 1 enota in pri vzpetinah prav tako 1 enota.

V prvi skupini enot oblikovanosti površja z ravninami sta v Sloveniji 2 enoti:

- ravne ravnine pokrivajo pol odstotka površja Slovenije in v celoti ležijo v panonski Sloveniji, predvsem vzdolž reke Mure;

- nagnjene ravnine pokrivajo prav tako pol odstotka površja Slovenije in skoraj v celoti ležijo v panonski Sloveniji, spet predvsem vzdolž reke Mure.

V drugi skupini enot oblikovanosti površja s planotami je le 1 enota:

- planote z griči pokrivajo komaj stotinko odstotka površja Slovenije in v celoti ležijo v panonski Sloveniji, najbolj tipična pokrajina te enote pa je Goričko na skrajnem severovzhodu države. 
V tretji skupini enot oblikovanosti površja, kamor so vključene ravnine z vzpetinami, so 3 enote:

- ravnine z griči pokrivajo $3 \%$ površja Slovenije in skoraj v celoti ležijo v panonski Sloveniji, predvsem vzdolž rek Mure in Drave in spodnjih tokovih njunih večjih pritokov;

- ravnine z nizkimi hribi pokrivajo $5 \%$ površja Slovenije in večinoma ležijo v panonski Sloveniji, slaba desetina tudi v dinarski Sloveniji;

- ravnine z visokimi hribi pokrivajo slabih $7 \%$ Slovenije in ležijo predvsem v kotlinah alpske Slovenije.

$\mathrm{V}$ četrti skupini enot oblikovanosti površja, kamor so vključene vzpetine z ravninami, so 4 enote:

- visoka gričevja z ravninami pokrivajo slab odstotek površja Slovenije in v celoti ležijo v panonski Sloveniji, najbolj tipični pokrajini te enote sta Goričko in Slovenske gorice;

- nizka hribovja z ravninami pokrivajo $4 \%$ površja Slovenije, štiri petine jih leži v panonski Sloveniji in petina v dinarski Sloveniji, najbolj tipične pokrajina te enote pa so Slovenske gorice, Goričko in Haloze;

- visoka hribovja z ravninami pokrivajo $20 \%$ površja Slovenije in so najbolj enakomerno razporejena enota po državi, dobra polovica jih leži v dinarski Sloveniji;

- gorovja z ravninami pokrivajo $2 \%$ površja Slovenije, večina jih leži v alpski Sloveniji, predvsem Ljubljanski kotlini.

V peti skupini enot oblikovanosti površja, kamor so vključene vzpetine, so 3 enote:

- nizka hribovja pokrivajo slab odstotek površja Slovenije in v celoti ležijo v panonski Sloveniji, v osredju Goričkega;

- visoka hribovja pokrivajo 30 \% površja Slovenije, so razmeroma enakomerno razporejena po Sloveniji, večina jih leži v alpski in dinarski Sloveniji, najbolj tipična pokrajina te enote pa je Posavsko hribovje;

- gorovja pokrivajo 27 \% površja Slovenije, štiri petine jih leži v alpski Sloveniji in petina v dinarski Sloveniji, najbolj tipična pokrajina te enote pa so Julijske Alpe.

Zanimivo je, v katere enote oblikovanosti površja se uvrščajo nekatere večje slovenske pokrajine:

- panonsko gričevje Goričko na severovzhodu Slovenije: dobra tretjina pokrajine leži v enoti nizka hribovja $\mathrm{z}$ ravninami, tretjina $\mathrm{v}$ enoti nizka hribovja, dobra desetina $\mathrm{v}$ enoti ravnine $\mathrm{z}$ nizkimi hribi in prav tako dobra desetina $\mathrm{v}$ enoti visoka gričevja $\mathrm{z}$ ravninami, slaba desetina pa še v enoti ravnine $\mathrm{z}$ griči;

- sredozemska kraška planota Kras v zaledju Trsta na jugozahodu Slovenije: skoraj štiri petine pokrajine ležijo v enoti visoka hribovja z ravninami;

- nizki dinarski kraški ravnik Bela krajina na jugovzhodu Slovenije: slaba polovica pokrajine leži v enoti visoka hribovja $\mathrm{z}$ ravninami, slaba četrtina $\mathrm{v}$ enoti ravnine $\mathrm{z}$ nizkimi hribi in dobra petina $\mathrm{v}$ enoti nizka hribovja z ravninami;

- obsežno Posavsko hribovje vzhodno od Ljubljane: več kot štiri petine pokrajine leži v enoti visoka hribovja; - planotasto gorovje Pohorje zahodno od Maribora: štiri petine pokrajine leži v enoti gorovja, dobra desetina $\mathrm{v}$ enoti ravnine $\mathrm{z}$ visokimi hribi in slaba desetina $\mathrm{v}$ enoti visoka hribovja;

- Julijske Alpe na severozahodu Slovenije: $99 \%$ pokrajine leži v enoti gorovja.

Zadnje tri slovenske pokrajine so glede na svoje dejanske morfološke značilnosti po Hammondovi metodi uvrščene razmeroma dobro, v prave enote oblikovanosti površja, prve tri pa slabše.

\section{Prilagoditev Hammondove metode značilnostim površja v Sloveniji}

Zaradi slabosti, ki so se pokazale pri klasifikaciji površja v Sloveniji po izvirni Hammondovi metodi, smo se odločili, da metodo ustrezno priredimo. Za ozemeljsko majhno, vendar reliefno izredno pestro Slovenijo z raznolikimi geomorfnimi procesi (Zorn in Komac 2004; Zorn in Komac 2007; Hrvatin in Perko 2008) je kvadratna celica $\mathrm{z}$ osnovnico skoraj $10 \mathrm{~km}$ bistveno prevelika.

Že kvadratna oblika celice ni najboljša, saj v kvadratu robne točke niso enako oddaljene od središča. Pri prirejeni metodi smo se zato odločili za osnovno celico okrogle oblike s površino, ki se najbolj približa kvadratnemu kilometru. Glede na to, da smo izračune opravljali na petindvajsetmetrskem digitalnem modelu višin, smo izbrali krog z radijem 23 enot ali $575 \mathrm{~m}$ in površino $1,03 \mathrm{~km}^{2}$. Vsaka tako določena celica je vključevala 1653 točk digitalnega modela višin.

Pri izvirni Hammondovi metodi si osnovne kvadratne celice sledijo ena za drugo brez medsebojnega prekrivanja, mi pa smo se odločili za bolj natančno metodo delnega prekrivanja osnovne krožne celice s petindvajsetmetrskim korakom oziroma zamikom. 


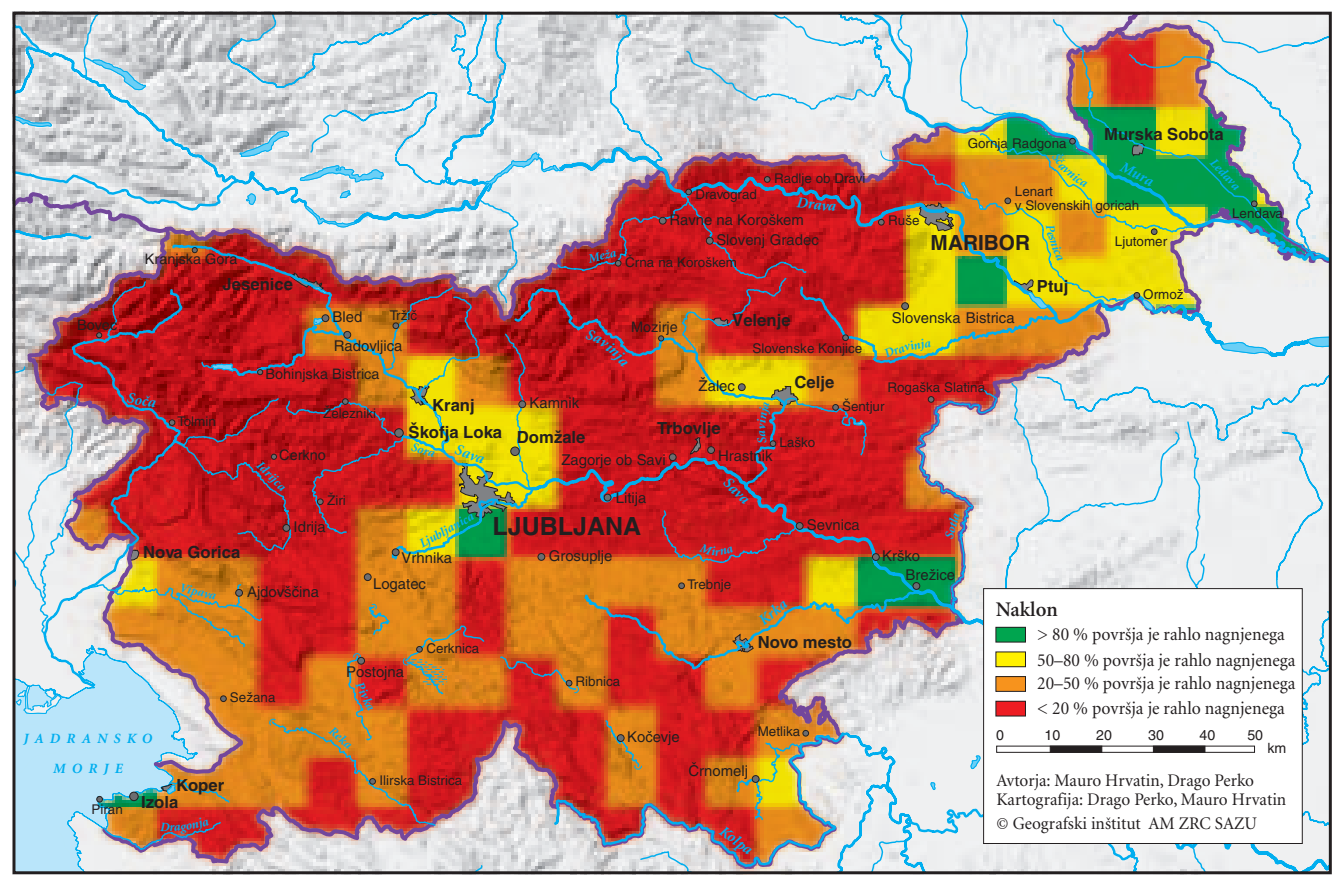

Slika 1: Prva Hammnondova prvina: naklon.

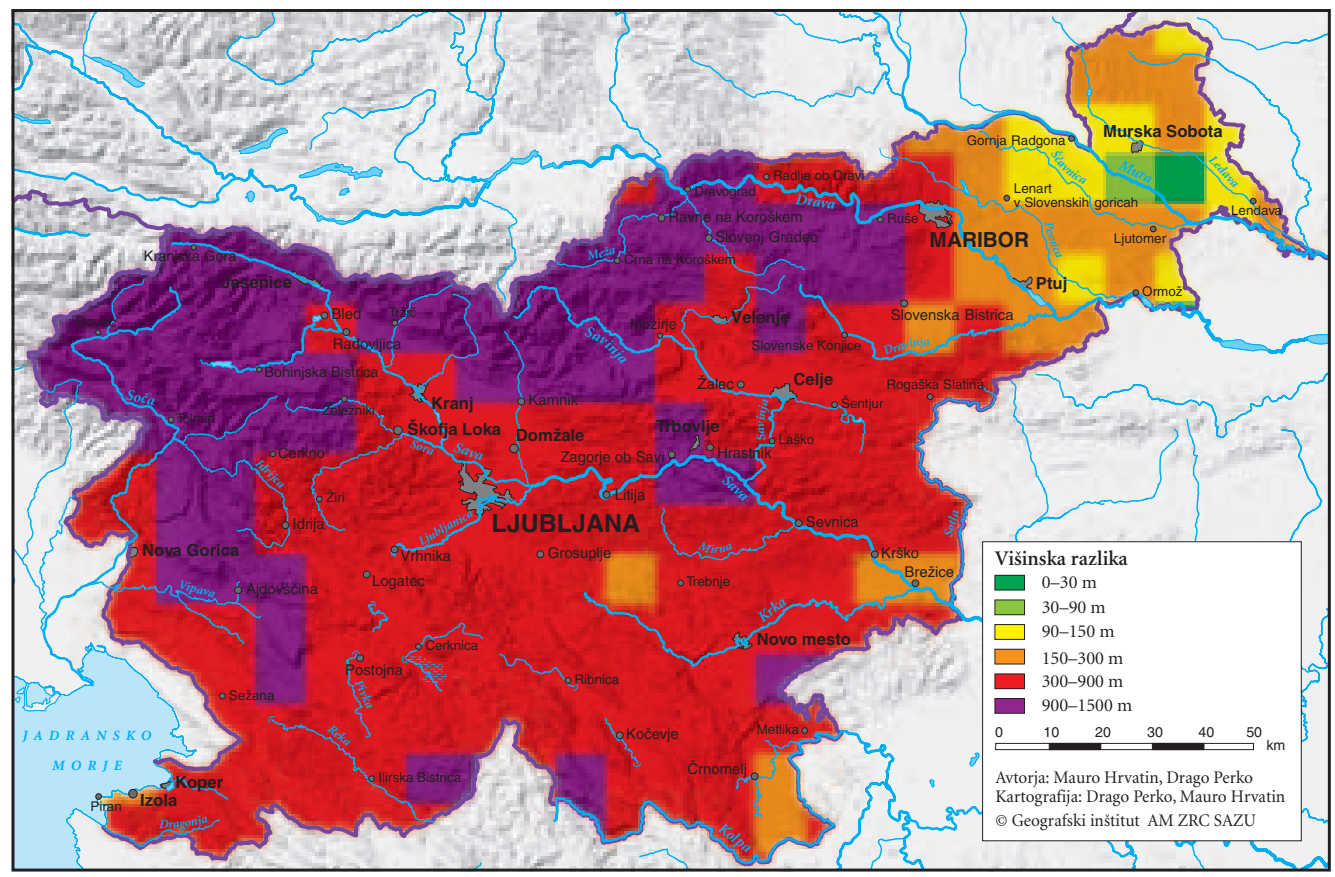

Slika 2: Druga Hammnondova prvina: višinska razlika. 


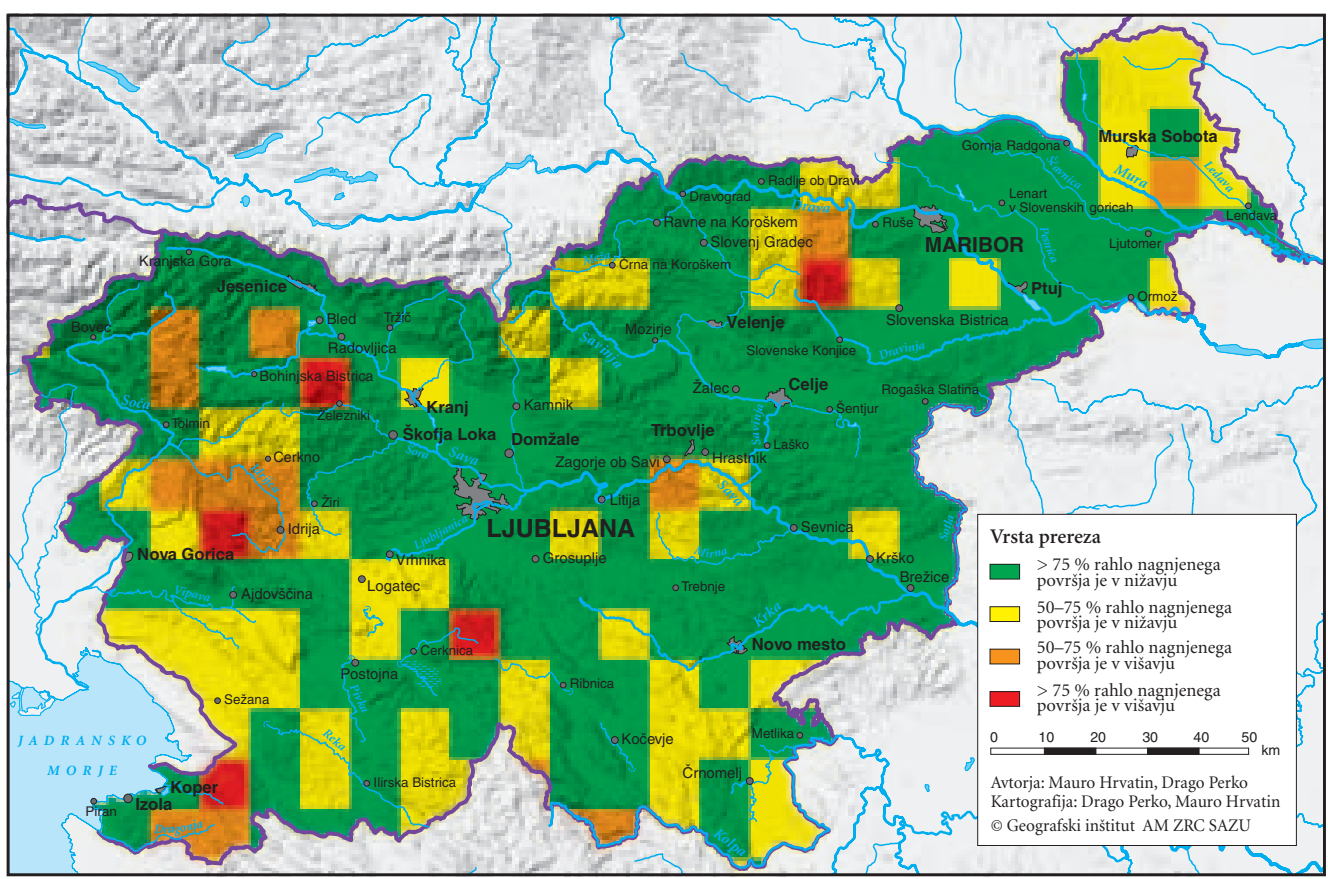

Slika 3: Tretja Hammnondova prvina: lega rahlo nagnjenega površja.

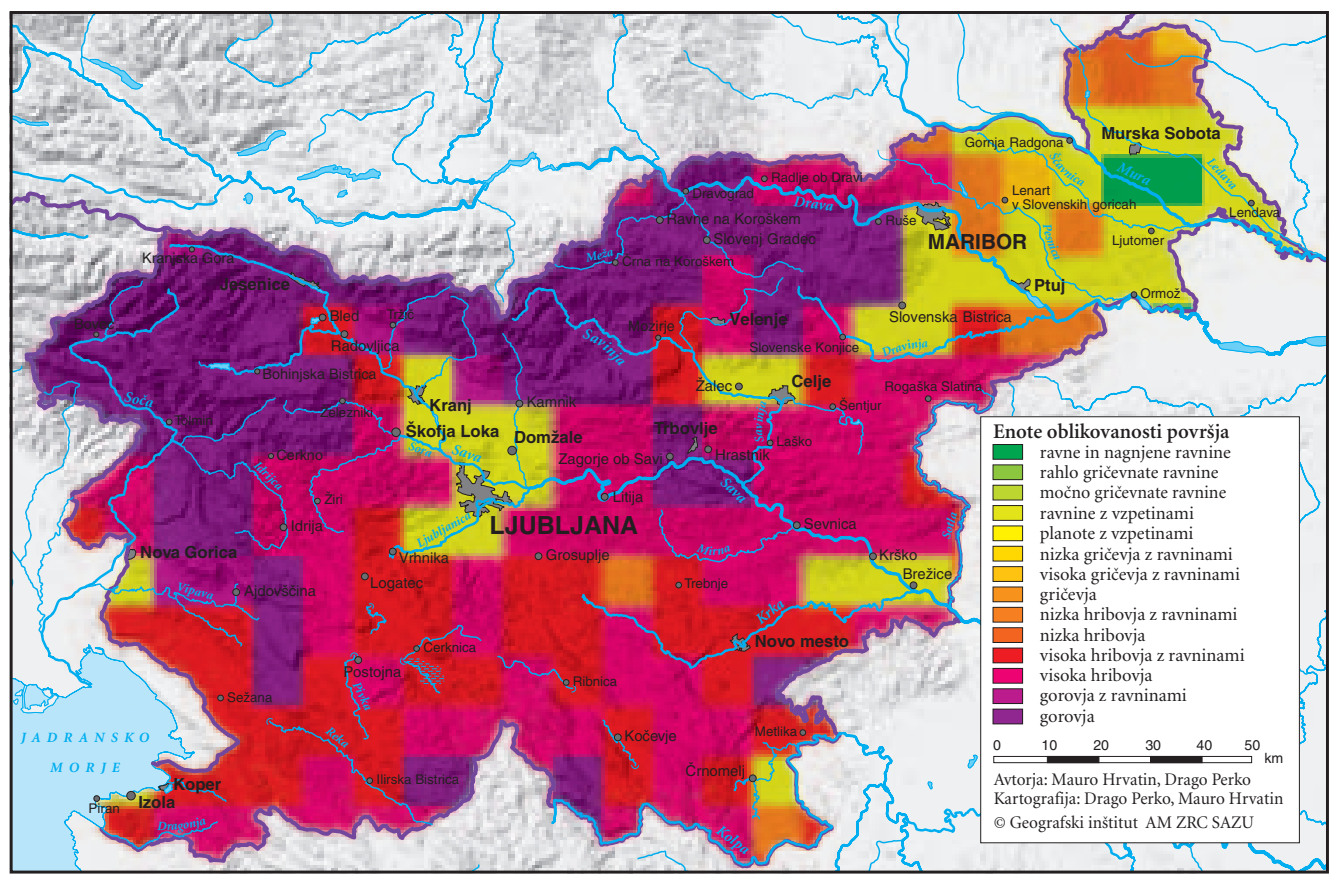

Slika 4: Izvirne Hammondove enote oblikovanosti površja v Sloveniji. 
Slika 5: Prirejene Hammondove enote oblikovanosti površja v Sloveniji.

Prirediti smo morali tudi obseg posameznih razredov. Pri prvi prvini smo deleže rahlo nagnjenega površja spremenili takole:

- A: $>99 \%$ površja je rahlo nagnjenega,

- B: $50-99 \%$ površja je rahlo nagnjenega,

- C: 1-50\% površja je rahlo nagnjenega,

- D: $<1 \%$ površja je rahlo nagnjenega;

pri drug prvini pa višinske razlike takole:

- 1: 0-50 m,

- 2: $50-100 \mathrm{~m}$,

- 3: 100-200 m,

- 4: 200-300 m,

- 5: 300-400 m,

- 6: $400 \mathrm{~m}$ in več.

Nove meje razredov prve in druge prvine smo določili empirično z večkratnim poizkušanjem, kako se posamezne spremembe mej razreda približajo dejanskim razmeram v pokrajini (Hrvatin in Perko 2009). Tudi ostali avtorji sodobnih členitev so morali Hammondovo metodo prilagoditi reliefnim značilnostim obravnavanih pokrajin (Dikau 1991; Brabyn 1998; Gallant s sodelavci 2005).

Pri poimenovanju enot oblikovanosti površja povzroča težavo pomenska neusklajenost izrazov za vzpetine med angleškim in slovenskim jezikom, zato smo morali tudi izraze ustrezno prilagoditi (preglednica 1).

Preglednica 1: Približni ekvivalenti angleških in slovenskih izrazov glede na višinske razlike.

\begin{tabular}{lll}
\hline krajevne višinske razlike & angleški izraz za vzpetine & slovenski izraz za vzpetine \\
\hline $0-30 \mathrm{~m}$ & plains & ravnine \\
$50-100 \mathrm{~m}$ & low hills & nizki griči \\
$100-200 \mathrm{~m}$ & hills & visoki griči \\
$200-300 \mathrm{~m}$ & high hills & nizki hribi \\
$300-900 \mathrm{~m}$ & low mountains & visoki hribi \\
$900-1500 \mathrm{~m}$ & high mountains & gore \\
\hline
\end{tabular}

\section{Sklep}

Hammondova metoda se je pri členitvi površja Združenih držav Amerike izkazala za razmeroma kakovostno. V Sloveniji, kjer se morfološke značilnosti površja prostorsko hitro spreminjajo, pa je metoda premalo podrobna. Številne slovenske pokrajine se zato uvrščajo v enote, ki ne kažejo njihovih dejanskih morfoloških značilnosti, saj se zaradi velikosti osnovne kvadratne celice upoštevajo tudi morfološke značilnosti njihovih sosednjih pokrajin. Izvirna temeljna celica s površino skoraj $100 \mathrm{~km}^{2}$ je namreč za ugotavljanje vseh treh Hammondovih prvin za Slovenijo bistveno prevelika.

Hammondova metoda je torej bolj uspešna pri členitvi morfološko obsežnih in razmeroma enotnih pokrajin, novejše študije (Dikau 1991; Brabyn 1998; Gallant s sodelavci 2005) pa kažejo, da je lahko uspešna tudi pri členitvi morfološko pestrejših pokrajin, če jo ustrezno priredimo. Morfološkim značilnostim pokrajine se lahko prilagodimo tako, da spremenimo obliko in velikost temeljne celice ter meje razredov klasifikacijskih prvin. S tako prirejeno metodo smo v Sloveniji določili 19 enot oblikovanosti površja (Hrvatin in Perko 2009).

Po izvirni Hammondovi metodi naj bi bilo v Sloveniji dve tretjini površja s hribi, slaba tretjina z gorami, komaj $4 \%$ z griči in niti odstotek ravnin brez vzpetin, po prirejeni Hammondovi metodi pa naj bi bilo v Sloveniji dobri dve petini površja z griči, slaba tretjina s hribi, dobra desetina $z$ gorami in slaba desetina $\mathrm{z}$ ravninami brez vzpetin (preglednica 2). 


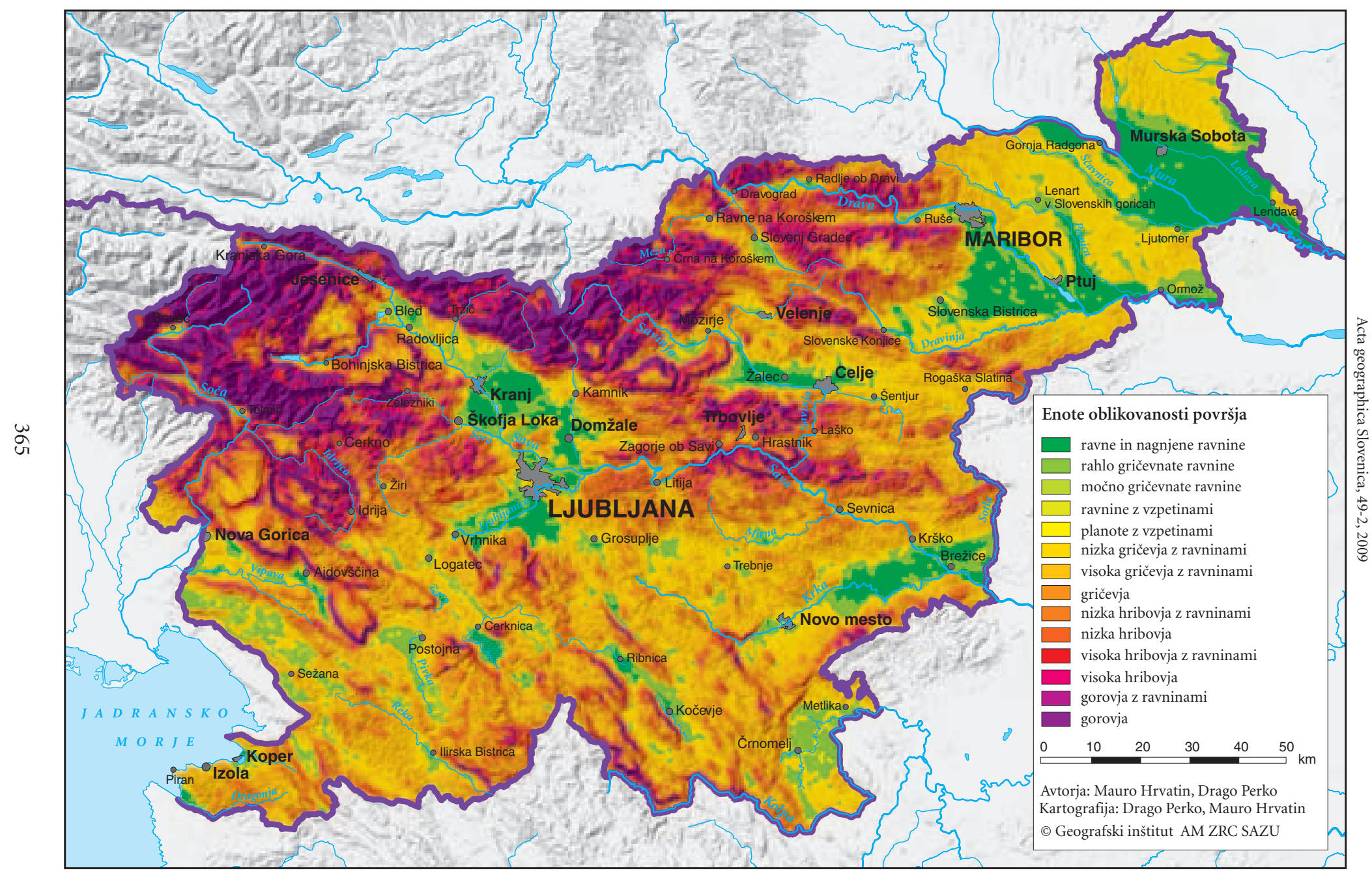


Mauro Hrvatin, Drago Perko, Primernost Hammondove metode za določanje enot oblikovanosti površja v Sloveniji

Preglednica 2: Primerjava izvirnih in prirejenih Hammondovih enot oblikovanosti površja v Sloveniji.

\begin{tabular}{|c|c|c|c|c|c|}
\hline \multirow[t]{2}{*}{ enota površja } & \multicolumn{2}{|c|}{ izvirna enota } & \multicolumn{2}{|c|}{ prirejena enota } & \multirow{2}{*}{$\begin{array}{c}\text { razmerje med izvirno }(\mathrm{I} \\
\text { in prirejeno }(\mathrm{P}) \text { enoto }\end{array}$} \\
\hline & ha & $\%$ & ha & $\%$ & \\
\hline ravne ravnine & $9.981,16$ & 0,49 & $139.524,13$ & 6,88 & 0,07 \\
\hline nagnjene ravnine & $9.337,93$ & 0,46 & 0,00 & 0,00 & - \\
\hline rahlo gričevnate ravnine & 0,00 & 0,00 & $142.485,71$ & 7,03 & 0,00 \\
\hline močno gričevnate ravnine & 0,00 & 0,00 & $93.131,54$ & 4,59 & 0,00 \\
\hline planote z griči & 193,21 & 0,01 & $1.116,62$ & 0,06 & 0,17 \\
\hline planote z nizkimi hribi & 0,00 & 0,00 & 37,37 & 0,00 & 0,00 \\
\hline planote z visokimi hribi & 0,00 & 0,00 & 3,50 & 0,00 & 0,00 \\
\hline planote z gorami & 0,00 & 0,00 & 0,00 & 0,00 & - \\
\hline ravnine z griči & $60.933,96$ & 3,01 & $18.939,92$ & 0,93 & 3,22 \\
\hline ravnine z nizkimi hribi & $110.547,32$ & 5,45 & $1.550,15$ & 0,08 & 71,31 \\
\hline ravnine z visokimi hribi & $137.072,88$ & 6,76 & 210,51 & 0,01 & 651,13 \\
\hline ravnine z gorami & 0,00 & 0,00 & 62,36 & 0,00 & 0,00 \\
\hline nizka gričevja z ravninami & 0,00 & 0,00 & $249.580,81$ & 12,31 & 0,00 \\
\hline visoka gričevja z ravninami & $14.140,83$ & 0,70 & $539.664,56$ & 26,62 & 0,03 \\
\hline nizka hribovja z ravninami & $81.976,40$ & 4,04 & $319.033,14$ & 15,74 & 0,26 \\
\hline visoka hribovja z ravninami & $398.932,95$ & 19,68 & $116.088,67$ & 5,73 & 3,44 \\
\hline gorovja z ravninami & $41.094,11$ & 2,03 & $67.725,60$ & 3,34 & 0,61 \\
\hline gričevja & 0,00 & 0,00 & $1.697,36$ & 0,08 & 0,00 \\
\hline nizka hribovja & $14.720,70$ & 0,73 & $54.580,41$ & 2,69 & 0,27 \\
\hline visoka hribovja & $600.192,86$ & 29,61 & $100.372,14$ & 4,95 & 5,98 \\
\hline gorovja & $548.167,93$ & 27,04 & $181.487,74$ & 8,95 & 3,02 \\
\hline skupaj & $2.027 .292,25$ & 100,00 & $2.027 .292,25$ & 100,00 & 1,00 \\
\hline
\end{tabular}

\section{Viri in literatura}

Glej angleški del prispevka. 